\title{
Siirtolaisuutemme nykyisestä luonteesta Suomi-Seuralle vuonna 1959 tehtyjen tiedustelujen valossa
}

\author{
Valtiot. maist. URHO MATTILA \\ Suomi-Seuran siirtolaisosasto
}

Suomesta muihin maihin tapahtuvasta muuttoliikkeestä esiintyy julkisuudessa monenlaisia tietoja. Milloin mainitaan kymmenien tuhansien maanmiestemme muuttavan vuosittain kotimaasta, milloin taas sanotaan maastamuuttoa tapahtuvan »jossain määrin». Tämä johtuu siitä, ettei siirtolaisuudesta voida nykyisin esittää tarkkoja numerotietoja, vaan on tyydyttävä arvioihin. Suurimpana syynä tähän on se, että toisiin pohjoismaihin muutettaessa ei vuodesta 1954 lähtien ole enää tarvittu passia, ja siirtolaisuusluvut on laskettu juuri siirtolaisiksi ilmoittautuneiden passinottajien perusteella. Seuraavan selvityksen tarkoituksena on valaista viime vuosina maastamme tapahtunutta siirtolaisuutta ja selostaa vuoden 1959 osalta tarkemmin tämän muuttoliikkeen luonnetta.

Jotta maastamuuton nykyisestä suuruudesta voitaisiin saada selvä kuva, on syytä tutustua Suomesta aikaisempina vuosina tapahtuneeseen siirtolaisuuteen. Sitä kuvaavat seuraavat maasta lähteneiden vuosittaista keskimäärää osoittavat luvut:

\section{Kausi}

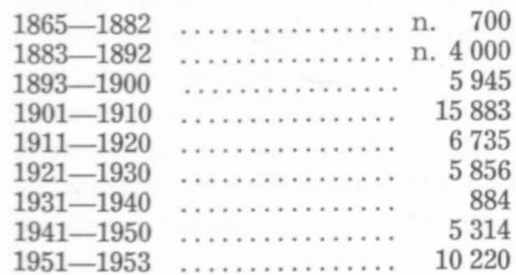

Vuoden 1954 puolivälin jälkeen ei ole ollut saatavissa tarkkoja tietoja Skandinavian maihin, etupäässä Ruotsiin, muuttaneiden maanmiestemme määrästä, koska pohjoismainen passiunioni perustettiin niihin aikoihin. Vuosien 1960 - 61 vaihteessa Ruotsissa oli n. 47.000 työssä olevaa suomalaista, joten siellä asuvien maanmiestemme kokonaismäärä lienee ollut perheenjäsenet mukaanlukien jonkin verran yli 100.000 . Sitä paitsi Ruotsissa asuu runsaasti Ruotsin kansalaisuuden saaneita suomalaisia, jotka eivät ole em. luvuissa mukana.

Suomen kannalta kaksi tärkeintä valtamerten takaista siirtolaisia vastaanottavaa maata ovat nykyisin Kanada ja Australia. Näistä maista saatujen virallisten tietojen mukaan on Kanadaan saapunut vuodesta 1946 vuoteen 1960 kaikkiaan n. 17600 suomalaista ja Australiaan yli 6000 . Vuosina 1956-60 Suomesta Kanadaan ja Australiaan tapahtunutta siirtolaisuutta valaisee oheinen kuvio.

Maastamme muuttaa edelleen n. 500 henkeä vuosittain Yhdysvaltoihin kiintiön ollessa 566. Saman verran uskotaan suomalaisia siirtyvän vuosittain muihin maihin kuin Skandinaviaan, Kanadaan, Australiaan ja Yhdysvaltoihin.

Luonnollisesti monet siirtolaiset palaavat takaisin kotimaahan, kuka aikaisemmin, kuka vasta monia vuosia myöhemmin. Yleensä arvioidaan, että lähteneistä siirtolaisista suunnilleen joka kolmas palaa takaisin synnyinmaahansa, tarkkoja tietoja heidän lukumäärästään ei ole saatavissa. Eräässä Valtakunnansuunnittelu- 


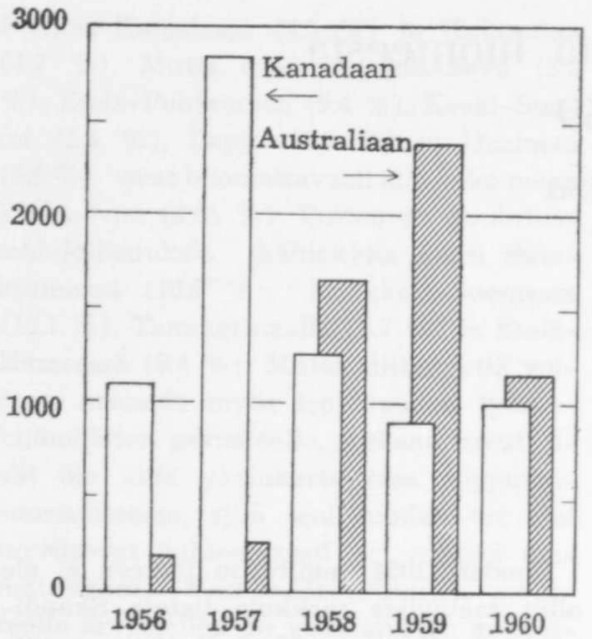

Kanadaan ja Australiaan saapuneiden suomalaisten määrät vuosina 1956-1960. Kanadaan

toimiston selvityksessä on nettosiirtolaisuuden arvioitu olleen vuosina 1951-1958 lähes 9000 henkeä vuotta kohden.

Siirtolaisuus on siten ollut vain kuluvan vuosisadan ensimmäisellä vuosikymmenellä vilkkaampaa kuin 1950-luvulla.

Suomessa annettiin vuonna 1956 laki siirtolaisvälityksestä. 1950-luvun alkupuolella maassamme esiintyi jossain mitassa siirtolaisvärväystoimintaa, jonka puitteissa maanmiehiämme houkuteltiin lähtemään Suomesta antamalla heille harhaanjohtavia ja suorastaan vääriä tietoja. Samanaikaisesti eräät »liikemiehet» pyrkivät hankkimaan rahallista ansiota siirtolaisten kustannuksella järjestämällä heille yhteismatkoja. Edellämainitun lain avulla haluttiin estää tällainen toiminta. Sen nojalla voidaan kuitenkin antaa erityinen lupa siirtolaisinformaation harjoittamiseen. Toistaiseksi sellainen on annettu vain Suomi-Seuralle. Tämän seuran siirtolaisosaston velvollisuutena on antaa tiedustelijoille mahdollisimman tarkkoja tietoja muiden maiden olosuhteista ja niihin pääsystä.

Tiedustelujen pohjalla Suomi-Seuran siirtolaisosastolla on tehty selvitys, joka pyrkii valaisemaan siirtolaisuuden nykyistä luonnetta. Selvitys ei sellaisenaan päde todella siirtolaisiksi lähteneisiin. Se antanee kuitenkin sangen luotettavan kuvan myös viimeksi mainitusta ryhmästä, ts. maasta poispäin suuntautuvan muuttoliikkeen rakenteesta. Selostuksessa pyritään mainitsemaan ne seikat, joissa lähteneiden siirtolaisten jakautumat todennäköisesti poikkeavat tutkimuksen kohteena olleiden siirtolaistiedustelijoiden jakautumasta.

Taulukoissa esiintyvät luvut perheenjäsenten määrästä on saatu kertomalla naimisissa olevien tiedustelijoiden määrä kahdella ja laskemalla tulos yhteen naimattomien tiedustelijoiden ja lasten luvun kanssa.

Vuoden 1959 aikana Suomi-Seuran siirtolaisosastolle osoitettiin 3725 maastamuuttotiedustelua, joista suurin osa eli $91.5 \%$ koski Australiaa (taulu 1). Jos otetaan huomioon myös tiedustelijoiden perheenjäsenet, niin Australian osuus nousee $93.3 \%$ :iin. Lisäksi herättää huomiota se, että Australian oloista kiinnostuneilla on ollut huomattavan runsaasti lapsia eli $95.2 \%$ kaikista. Australian jälkeen tiedustelut ovat useimmissa tapauksissa koskeneet Kanadaa, Yhdysvaltoja ja Uutta Seelantia. Muiden maiden ryhmään kuului 12 maata.

Mainittuja lukuja tarkastellessa voidaan todeta, että Australiaan aikoneista ovat todennäköisesti useimmat, mutta Kanadaan, Yhdysvaltoihin ja varsinkin Ruotsiin pyrkineistä vain suhteellisen harvat käyttäneet hyväkseen siirtolaisosaston suomaa mahdollisuutta saada tietoja ko. maissa vallitsevista olosuhteista. Yhteyden ottaminen siirtolaisosastoon ei näet ole ehtona siirtolaiseksi lähtemiselle.

Australiaan aikoneista vain joka yhdennellätoista on ollut siellä omaisia tai tuttavia, kun taas Kanadaan tiedustelleista joka kolmannella ja Yhdysvaltoihin pyrkineistä joka toisella on ollut perillä omaisia tai tuttavia. Tämä johtuu tietenkin siitä, että valtaosa aikaisemmista siirtolaisista on mennyt Amerikan mantereelle. Keskimäärin joka yhdeksännellä on ollut määrämaassa henkilö, jonka puoleen hän on voinut tarpeen vaatiessa kääntyä. 
Taulu 1. Siirtolaistiedustelijain jakautuma määrämaittain v. 1959 .

\begin{tabular}{|c|c|c|c|c|c|c|c|c|}
\hline \multirow[b]{2}{*}{ Määrämaa } & \multirow{2}{*}{ 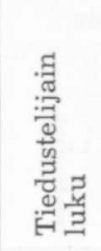 } & \multicolumn{2}{|c|}{ Miehiä } & \multicolumn{2}{|c|}{ Naisia } & \multirow[b]{2}{*}{ 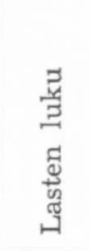 } & \multirow{2}{*}{ 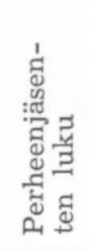 } & \multirow{2}{*}{ 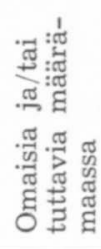 } \\
\hline & & 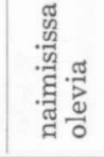 & 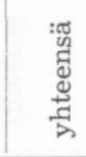 & 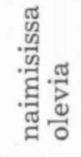 & 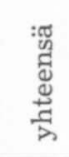 & & & \\
\hline Australia ........ & 3408 & 1657 & 3101 & 217 & 307 & 3605 & 8887 & 297 \\
\hline Kanada......... & 125 & 46 & 100 & 17 & 25 & 79 & 267 & 46 \\
\hline Yhdysvallat..... & 66 & 19 & 56 & 8 & 10 & 31 & 124 & 31 \\
\hline Uusi Seelanti .... & 36 & 15 & 34 & 1 & 2 & 35 & 87 & 1 \\
\hline Etelä-Afrikka .... & 17 & 4 & 17 & - & - & 5 & 26 & 2 \\
\hline Ruotsi $\quad \ldots \ldots \ldots \ldots$ & 13 & 3 & 11 & 1 & 2 & 5 & 22 & 2 \\
\hline Muut maat ...... & 48 & 8 & 40 & 5 & 8 & 11 & 72 & 4 \\
\hline Määrämaa ei selvillä & 12 & 9 & 9 & 2 & 3 & 14 & 37 & 一 \\
\hline Yhteensä & 3725 & 1761 & 3368 & 251 & 357 & 3785 & 9522 & 383 \\
\hline
\end{tabular}

$\mathrm{T}$ a u lu 2. Siirtolaistiedustelijoiden jakautuma talousalueittain v. 1959.

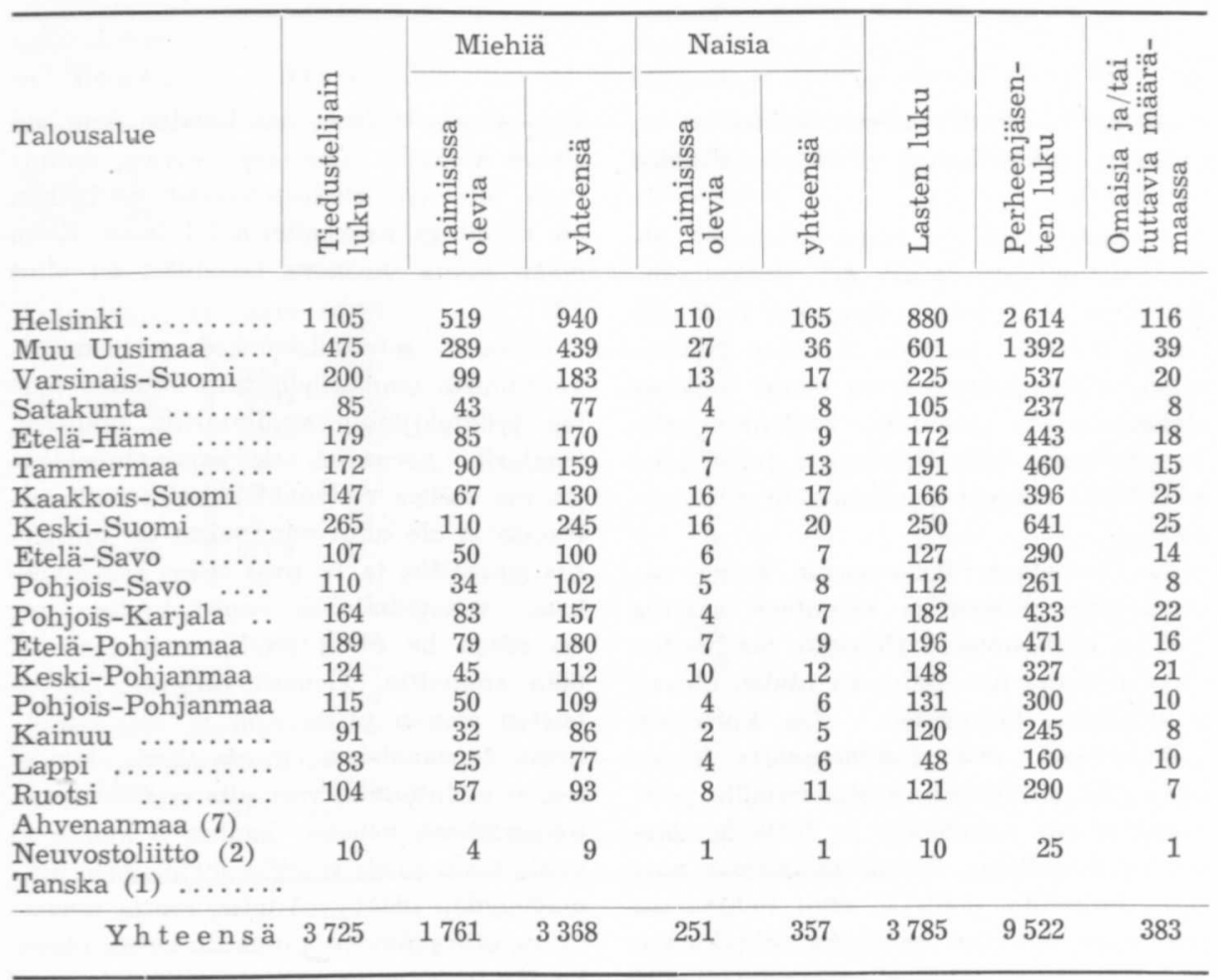

Ruotsista, Neuvostoliitosta (itärajamme takana olevilta voimalaitostyömailta) ja Tanskasta käsin tehtiin 107 siirtolaistie- dustelua, jotka on otettu tutkimukseen mukaan. Tiedot on annettu luottamuksellisina, joten Ahvenanmaalta, Neuvostolii- 
Ta ulu 3. Siirtolaistiedustelijain jakautuma ammattialoittain v. 1959 .

\begin{tabular}{|c|c|c|c|c|c|c|c|c|}
\hline \multirow[b]{2}{*}{ Ammattiryhmä } & \multirow{2}{*}{ 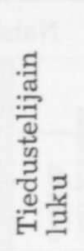 } & \multicolumn{2}{|c|}{ Miehiä } & \multicolumn{2}{|c|}{ Naisia } & \multirow[b]{2}{*}{ 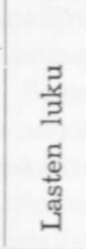 } & \multirow{2}{*}{ 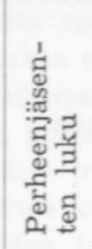 } & \multirow{2}{*}{ 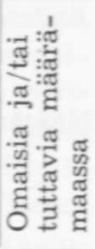 } \\
\hline & & 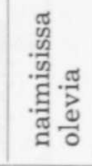 & 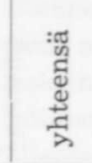 & 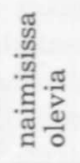 & 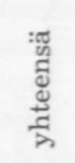 & & & \\
\hline Teollisuustyöntekijät $\quad \ldots \ldots \ldots$ & 878 & 471 & 808 & 50 & 70 & 955 & 2354 & 93 \\
\hline \multirow{2}{*}{\multicolumn{9}{|c|}{ Maanviljelijät, merimiehet ja }} \\
\hline & 404 & 180 & 388 & 11 & 16 & 530 & 1125 & 51 \\
\hline \multirow{2}{*}{\multicolumn{9}{|c|}{$\begin{array}{l}\text { Liikkeenharjoittajat ja liike- } \\
\text { apulaiset }\end{array}$}} \\
\hline & 345 & 172 & 292 & 37 & 53 & 355 & 909 & 43 \\
\hline Rakennustyömiehet $\ldots \ldots \ldots \ldots$ & 301 & 191 & 301 & - & - & 472 & 964 & 31 \\
\hline mattien harjoittajat ...... & 70 & 36 & 63 & 6 & 7 & 61 & 173 & 15 \\
\hline $\begin{array}{l}\text { Ei varsinaista tai tunnettua } \\
\text { ammattia } \ldots \ldots \ldots \ldots \ldots \ldots \ldots\end{array}$ & 696 & 207 & 633 & 45 & 63 & 487 & 1435 & 39 \\
\hline Yhteensä & 3725 & 1761 & 3368 & 251 & 357 & 3785 & 9522 & 383 \\
\hline
\end{tabular}

tosta ja Tanskasta tulleet tiedustelut on katsottu aiheelliseksi yhdistää yhdeksi ryhmäksi.

Tiedustelijoista on lähes kolmasosa ollut helsinkiläisiä (taulu 2). Pääkaupungin suuri osuus johtuu tietenkin siitä, että Suomi-Seuran toimisto sijaitsee Helsingissä. Pääkaupunkilaisten osuus kaikista tiedustelijoista herättää kuitenkin esiin kysymyksen, onko Helsingistä tullut jonkinlainen väliporras ulkomaille siirtymiselle.

Jos lasketaan Pohjanmaan kolme talousaluetta yhteen ja verrataan saatuja lukuja Uudenmaan (Helsinki poisluettuna) lukuihin, niin todetaan niiden olevan suhteellisen tasaväkisiä. On kuitenkin oletettavissa, että Pohjanmaalta lähtee enemmän siirtolaisia, koska monilla pohjalaisilla on sukulaisia ja tuttavia varsinkin Kanadassa. Mutta taulukosta voidaan kuitenkin päätellä, ettei Pohjanmaa ole enää nykyisin sellainen lähtökeskus kuin kuluvan vuosisadan ensimmäisillä vuosikymmenillä.

Taulussa 2 kiintyy huomio vielä siihen, että helsinkiläisillä tiedustelijoilla on ollut sangen vähän lapsia, vain 1.4 lasta naimi- sissa olevaa tiedustelijaa kohden, kun sen sijaan muualla Suomessa asuvien, naimisissa olevien tiedustelijoiden perheisiin on kuulunut keskimäärin 2.1 lasta. Koko maan osalta vastaava lapsiluku on ollut 1.9.

Taulu 3 selvittelee tiedustelijain jakautumista ammattialoittain. Muiden alojen työntekijöihin sisällytettiin teknikot, maalarit, asentajat, kirjapainotyöntekijät jne. Lähes viidennellä osalla tiedustelijoista ei ole ollut varsinaista tai tunnettua ammattia, ts. he ovat olleet asevelvollisia, sekatyömiehiä, opiskelijoita jne. tai sitten he eivät ole ilmoittaneet mitään ammattia. Yleensä väitetään siirtolaisten olevan yritteliästä ja ammattitaitoista kansanainesta, mutta tämä väite ei tunnu ehdottoman varmalta edellä olevan toteamuksen valossa. Taulun 3 avulla ei voida tosin saada selville siirtolaisten ammattitaidon pätevyysastetta, mutta ilmeistä on, että pätevien ammattimiesten ohella heidän joukossaan on runsaasti myös puoliammattimiehiä ja ammattitaidottomia.

Lähes neljäsosa tiedustelijoista on kuulunut teollisuustyöväkeen. Sen jälkeen tulevat autoalan työntekijät, maanvilje- 
Ta ulu 4. Siirtolaistiedustelijain ikäjakaumat v. 1959.

\begin{tabular}{|c|c|c|c|c|c|c|c|c|}
\hline \multirow[b]{2}{*}{ Ikä, v. } & \multirow{2}{*}{ 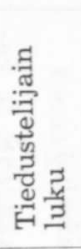 } & \multicolumn{2}{|c|}{ Miehiä } & \multicolumn{2}{|c|}{ Naisia } & \multirow[b]{2}{*}{ 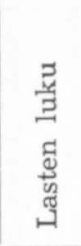 } & \multirow{2}{*}{ 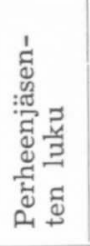 } & \multirow{2}{*}{ 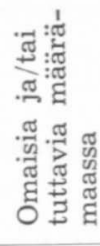 } \\
\hline & & 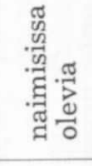 & 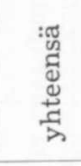 & 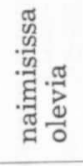 & 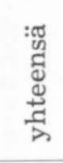 & & & \\
\hline$-19 \ldots$ & 141 & 4 & 106 & 26 & 35 & 9 & 180 & 17 \\
\hline $20-24$. & 828 & 151 & 735 & 65 & 93 & 162 & 1206 & 95 \\
\hline $25-29 \quad \ldots \ldots \ldots \ldots \ldots \ldots$ & 792 & 381 & 72 & 39 & 6 & 583 & 1795 & 76 \\
\hline $30-34 \quad \ldots \ldots \ldots \ldots \ldots$ & 549 & 358 & 51 & 24 & 33 & 707 & 1638 & 49 \\
\hline $35-39 \quad \ldots \ldots \ldots \ldots \ldots$ & 387 & 281 & 357 & 22 & 3 & 703 & 1393 & 35 \\
\hline $40-44 \quad \ldots \ldots \ldots \ldots \ldots$ & 288 & 229 & 26 & 19 & 28 & 648 & 1184 & 34 \\
\hline $45-49 \quad \ldots \ldots \ldots \ldots \ldots$ & 220 & 172 & 202 & 15 & 18 & 518 & 925 & 36 \\
\hline $50-54 \ldots \ldots \ldots \ldots \ldots$ & 67 & 54 & 62 & 4 & 5 & 140 & 265 & 15 \\
\hline $55-59 \ldots \ldots \ldots \ldots \ldots$ & 18 & 13 & 17 & 1 & 1 & 36 & 68 & 4 \\
\hline $60-\quad \ldots \ldots \ldots \ldots \ldots \ldots$ & 5 & - & 1 & 4 & 4 & - & 9 & $\overline{29}$ \\
\hline Ikä tuntematon $\ldots \ldots$. & 430 & 118 & 385 & 32 & 45 & 279 & 859 & 22 \\
\hline Yhteensä & 3725 & 1761 & 3368 & 251 & 357 & 3785 & 9522 & 383 \\
\hline
\end{tabular}

Taulu 5. Siirtolaistiedustelijoiden siviilisääty ja lasten lukumäärä v. 1959.

Siviilisääty, lasten luku
Täysi-

ikäisten luku

\section{Lasten \\ luku}

Yhteensä

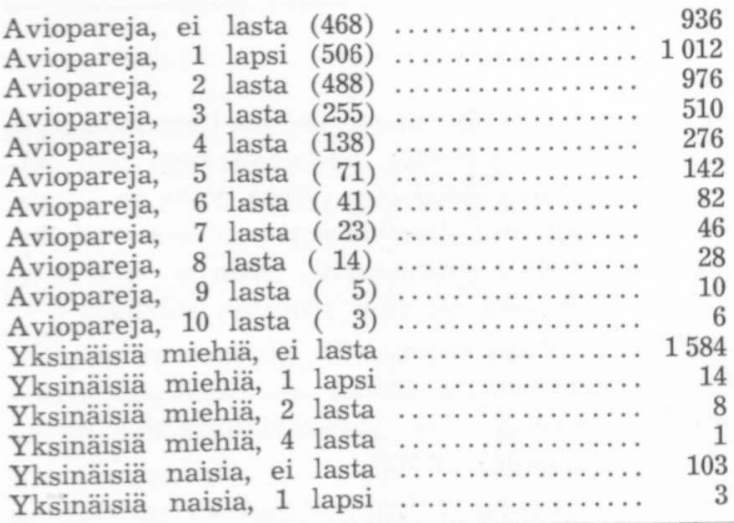

Yhteensä 5737

\begin{tabular}{rr}
- & 936 \\
506 & 1518 \\
765 & 1952 \\
552 & 1275 \\
355 & 828 \\
246 & 497 \\
161 & 328 \\
112 & 207 \\
45 & 140 \\
30 & 55 \\
- & 36 \\
14 & 1584 \\
16 & 28 \\
4 & 24 \\
- & 5 \\
3 & 103 \\
\hline
\end{tabular}

3785

9522 lijät ja rakennusmiehet. Erityisesti kiintyy huomio siihen, että maanviljelijöillä on sangen runsaasti lapsia, nimittäin 2.8 lasta naimisissa olevaa tiedustelijaa kohden, kun sen sijaan muita naimisissa ole- via tiedustelijoita kohden on ollut keskimäärin 1.8 lasta.

Taulussa 4 selvitellään tiedustelijain ikäjakautumaa. $20-24$ vuotiaiden määrä on ollut suurin, mutta jos otetaan huomioon 
Taulu 6. Siirtolaistiedustelijain jakautuma talousalueittain ja ammattiryhmittäin v. 1959.

\begin{tabular}{|c|c|c|c|c|c|c|c|c|c|c|}
\hline Talousalue & 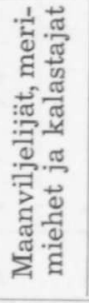 & 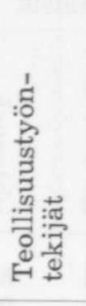 & 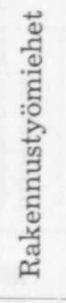 & 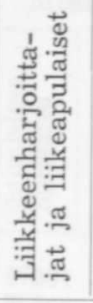 & 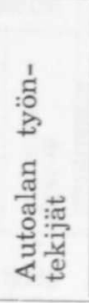 & 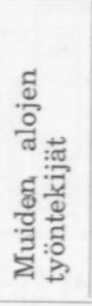 & 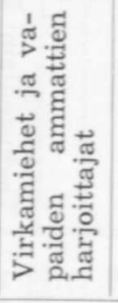 & 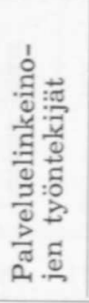 & 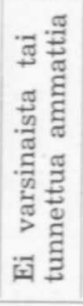 & 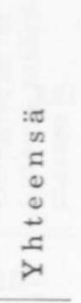 \\
\hline Helsinki & 11 & 306 & 114 & 131 & 123 & 166 & 30 & 122 & 102 & 1105 \\
\hline Muu Uusimaa & 54 & 112 & 20 & 68 & 52 & 87 & 6 & 32 & 44 & 475 \\
\hline Varsinais-Suomi & 19 & 66 & 19 & 8 & 13 & 20 & 4 & 10 & 41 & 200 \\
\hline Satakunta & 15 & 19 & 8 & 7 & 4 & 7 & - & 4 & 21 & 85 \\
\hline Etelä-Häme & 25 & 44 & 13 & 18 & 16 & 13 & 4 & 7 & 39 & 179 \\
\hline Tammermaa & 16 & 42 & 17 & 12 & 16 & 16 & 8 & 10 & 35 & 172 \\
\hline Kaakkois-Suomi & 14 & 39 & 14 & 15 & 7 & 21 & 1 & 10 & 26 & 147 \\
\hline Keski-Suomi & 40 & 51 & 24 & 18 & 34 & 20 & 6 & 7 & 65 & 265 \\
\hline Etelä-Savo & 21 & 19 & 6 & 10 & 9 & 11 & 1 & 5 & 25 & 107 \\
\hline Pohjois-Savo & 19 & 18 & 5 & 11 & 11 & 8 & - & 8 & 30 & 110 \\
\hline Pohjois-Karjala & 29 & 26 & 18 & 13 & 12 & 13 & 1 & 2 & 50 & 164 \\
\hline Etelä-Pohjanmaa & 50 & 35 & 7 & 8 & 17 & 13 & 1 & 6 & 52 & 189 \\
\hline Keski-Pohjanmaa & 38 & 20 & 5 & 6 & 7 & 6 & 1 & 6 & 35 & 124 \\
\hline Pohjois-Pohjanmaa & 14 & 23 & 18 & 7 & 7 & 8 & 3 & 5 & 30 & 115 \\
\hline Kainuu & 15 & 9 & 2 & 6 & 10 & 3 & 3 & 1 & 42 & 91 \\
\hline Lappi & 10 & 10 & 7 & 7 & 13 & 7 & 1 & 4 & 24 & 83 \\
\hline Ruotsi & 11 & 38 & 4 & - & 7 & 6 & - & 5 & 33 & 104 \\
\hline $\begin{array}{l}\text { Ahvenanmaa } \\
\text { Neuvostoliitto } \\
\text { Tanska }\end{array}$ & 3 & 1 & - & - & 3 & - & - & 1 & 2 & 10 \\
\hline Yhteensä & 404 & 878 & 301 & 345 & 361 & 425 & 70 & 245 & 696 & 3725 \\
\hline
\end{tabular}

myös tiedustelijoiden perheenjäsenet, niin 25-29-vuotiaiden ja 30-34-vuotiaiden ryhmät ovat suurimmat. Yleisesti uskotaan, että vain nuoret ihmiset noin 35vuotiaisiin asti olisivat kiinnostuneita muuttamisesta muihin maihin. Taulu kuitenkin osoittaa, että vanhemmatkin ovat taipuvaisia lähtemään siirtolaisiksi. Tiedustelijoista on suuri osa ollut yli 40 vuotiaita, onpa joukossa muutama yli 60 vuotiaskin mukana.

Taulussa 5 selvitellään siirtolaistiedustelijoiden siviilisäätyä ja lasten lukua perheissä. Siitä voidaan havaita, että naimisissa olevien tiedustelijoiden määrä on ollut hiukan suurempi kuin naimattomien lukujen ollessa 2012 ja 1713 . Perheellisistä tiedustelijoista on ollut eniten niitä, joilla on ollut 1 tai 2 lasta, vasta heidän jälkeensä tulee lapsettomien avioparien ryhmä. Jos taasen otetaan huomioon myös tiedustelijoiden perheenjäsenet, niin sellaisten avioparien ryhmä, joilla on 2 lasta, sijoittuu ylivoimaisesti ensimmäiseksi. Todellisia suurperheitä, joissa on ollut 9 tai 10 lasta, on ollut yhteensä kahdeksan.

Todettakoon, että jokainen varsinainen tiedustelija (3725) on edustanut keskimäärin 2.56 maastalähtöaikeissa olevaa henkilöä (9 522).

Taulun 6 lukujen mukaan siirtolaisuus koskee Helsingissä, Varsinais-Suomessa, Tampereen seudulla ja Ruotsissa olevien suomalaisten keskuudessa ennen kaikkea teollisuustyöväkeä. Pohjanmaalla se koskee luonnollisesti lähinnä maataloustyöntekijöitä, mutta ei enää yhtä selvästi Kajnuussa eikä Lapissa. Helsingissä palveluelinkeinojen työntekijät näyttävät myös olevan kiinnostuneempia maastamuutosta 
Ta ulu 7. Siirtolaistiedustelijain jakautuma talousalueittain ja määrämaittain v. 1959 .

\begin{tabular}{|c|c|c|c|c|c|c|c|c|c|}
\hline Talousalue & 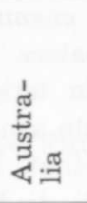 & 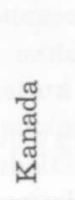 & 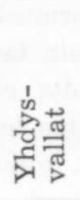 & 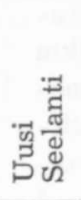 & 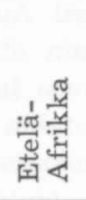 & 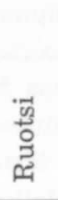 & 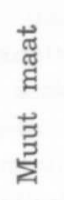 & 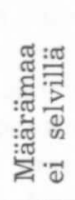 & 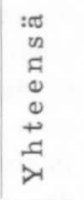 \\
\hline Helsinki & 1031 & 37 & 15 & 5 & 4 & 1 & 8 & 4 & 1105 \\
\hline Muu Uusimaa & 456 & 9 & 4 & 1 & - & 2 & 2 & 1 & 475 \\
\hline Varsinais-Suomi & 189 & 7 & 1 & 1 & 1 & - & 1 & - & 200 \\
\hline Satakunta & 78 & - & 1 & 2 & 1 & 2 & 1 & - & 85 \\
\hline Etelä-Häme & 159 & 7 & 6 & 2 & 1 & - & 4 & - & 179 \\
\hline Tammermaa & 142 & 11 & 6 & 3 & 4 & 2 & 4 & - & 172 \\
\hline Kaakkois-Suomi & 132 & 11 & 1 & - & - & - & 3 & - & 147 \\
\hline Keski-Suomi & 242 & 5 & 6 & 3 & - & 1 & 7 & 1 & 265 \\
\hline Etelä-Savo & 98 & 3 & 3 & 1 & 1 & 1 & - & - & 107 \\
\hline Pohjois-Savo & 100 & 4 & 1 & 2 & 1 & - & 1 & 1 & 110 \\
\hline Pohjois-Karjala & 155 & 3 & 2 & 1 & - & - & 3 & - & 164 \\
\hline Etelä-Pohjanmaa & 161 & 13 & 5 & 5 & - & - & 4 & 1 & 189 \\
\hline Keski-Pohjanmaa & 108 & 5 & 2 & 4 & - & 2 & 2 & 1 & 124 \\
\hline Pohjois-Pohjanmaa & la 106 & 1 & 2 & - & 1 & 2 & 3 & - & 115 \\
\hline Kainuu & 79 & 2 & 2 & 2 & 2 & - & 2 & 2 & 91 \\
\hline Lappi & 73 & 2 & 4 & 1 & 1 & - & 2 & - & 83 \\
\hline Ruotsi & 93 & 3 & 3 & 3 & - & - & 1 & 1 & 104 \\
\hline Ahvenanmaa & & & & & & & & & \\
\hline $\begin{array}{l}\text { Neuvostoliitto } \\
\text { Tanska }\end{array}$ & 6 & 2 & 2 & - & - & - & - & - & 10 \\
\hline Yhteensä & 3408 & 125 & 66 & 36 & 17 & 13 & 48 & 12 & 3725 \\
\hline
\end{tabular}

Taulu 8. Siirtolaistiedustelijain kielitaito v. 1959.

\begin{tabular}{|c|c|c|c|c|c|c|c|c|}
\hline \multirow[b]{2}{*}{ Kielitaito } & \multirow{2}{*}{ 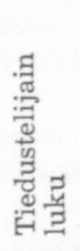 } & \multicolumn{2}{|c|}{ Miehiä } & \multicolumn{2}{|c|}{ Naisia } & \multirow[b]{2}{*}{ 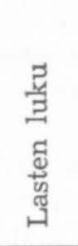 } & \multirow{2}{*}{ 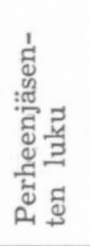 } & \multirow{2}{*}{ 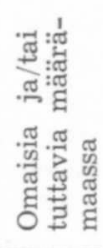 } \\
\hline & & 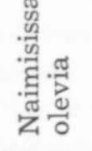 & 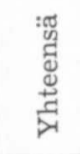 & 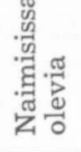 & 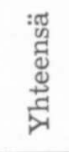 & & & \\
\hline $\begin{array}{l}\text { Vain suomea } \ldots \ldots \ldots \\
\text { Englantia }\end{array}$ & 2526 & 1205 & 2299 & 162 & 227 & 2719 & 6612 & 216 \\
\hline $\begin{array}{l}\text { Englantia } \\
\quad \text { hyvin } \ldots \ldots \ldots \ldots \\
\text { tyydyttävästi } \ldots \ldots \\
\text { välttävästi } \ldots \ldots \ldots \\
\text { hieman } \ldots \ldots \ldots \ldots \\
\text { Muita kieliä } \ldots \ldots \ldots\end{array}$ & $\begin{array}{r}50 \\
127 \\
191 \\
695 \\
136\end{array}$ & $\begin{array}{r}21 \\
44 \\
107 \\
325 \\
59\end{array}$ & $\begin{array}{r}41 \\
106 \\
175 \\
627 \\
120\end{array}$ & $\begin{array}{r}9 \\
15 \\
9 \\
48 \\
8\end{array}$ & $\begin{array}{r}9 \\
21 \\
16 \\
68 \\
16\end{array}$ & $\begin{array}{r}51 \\
90 \\
186 \\
628 \\
111\end{array}$ & $\begin{array}{r}131 \\
276 \\
493 \\
1696 \\
314\end{array}$ & $\begin{array}{r}9 \\
20 \\
31 \\
95 \\
12\end{array}$ \\
\hline Yhteensä & 3725 & 1761 & 3368 & 251 & 357 & 3785 & 9522 & 383 \\
\hline
\end{tabular}

kuin muualla Suomessa. Eri puolilla maata asuneet siirtolaistiedustelijat eivät erottaudu ammatillisesti kovinkaan jyrkästi toisistaan, vaan on jakautuminen verraten tasaista. Pohjois-Karjalasta, Pohjanmaalta ja Pohjois-Suomesta kotoisin olevat tiedustelijat eivät joka kolmannessa tai neljännessä tapauksessa ole ilmoittaneet mitään ammattia tai ovat selittäneet, ettei heillä ole varsinaista ammattia. Tällaisten henkilöiden määrä on Kainuun osalta lähes puolet. 
Jo aikaisemmista tauluista on voitu havaita v. 1959 tehtyjen tiedustelujen kohdistuneen melko yksipuolisesti Australiaan. Niin mielenkiintoista kuin olisikin saada tietää, missä osassa Suomea tunnetaan erikoista mielenkiintoa jotakin siirtolaismaata kohtaan, ei tästä seikasta voida päästä selville edellisen taulun 7 avulla. Australian osuus kaikista tiedusteluista on $91.5 \%$, mutta sen osuus jää kuitenkin alle 90 \%:n Etelä-Hämeessä, Tampereen seudulla, Kaakkois-Suomessa, Etelä- ja Keski-Pohjanmaalla, Kainuussa, Lapissa ja Ruotsista käsin tehtyjen tiedustelujen kohdalla. Pohjanmaalta, Kaakkois-Suomesta ja Tampereen ympäristöstä tulleet tiedustelut näyttävät kos keneen Australian ohella ensi sijassa Kanadaa.

Viimeinen taulu (taulu 8) osoittaa siirtolaistiedustelijoiden kielitaidon olleen sangen heikon, sillä $68 \%$ heistä on ilmoittanut osaavansa vain suomea. Yhteensä 1063 kysyjää on sanonut puhuvansa hieman tai sitä paremmin englantia. Muiden kielten kohdalla ilmoitettu taito ei tosin vastaa todellisuutta, sillä tiedustelijat ovat varmasti osanneet enemmän esim. ruotsia kuin taulukko ilmaisee. Selvityksen kannalta oli kuitenkin tarkoituksenmukaista ottaa huomioon vain sen maan kielen taito, johon tiedustelijat ilmoittivat pyrkivänsä. Useimmat tiedustelut koskivat anglosaksisia maita, joten kysyjät luonnollisesti ilmoittivat, missä määrin he osaavat englantia.

Englanninkieltä osaavista 1063 tiedustelijasta on 155 ilmoittanut, että heillä on määrämaassa omaisia tai tuttavia. Tähän ryhmään kuuluvista on siis lähes yhdellä kuudesta ollut henkilökohtaisia yhteyksiä määrämaahan. Sen sijaan vain suomea osaaville on ainoastaan yhdellä kahdestatoista ollut perillä omaisia tai tuttavia. Kielitaitonsa ja henkilökohtaisten yhteyksiensä ansiosta näillä 155 tiedustelijalla on ollut hyvät mahdollisuudet päästä elämisen alkuun uudessa kotimaassa. Enemmistöllä sen sijaan ei ole ollut läheskään niin hyvää lähtökohtaa. 